Review Article

\title{
Proton Pump Inhibitors and Fractures in Adults: A Critical Appraisal and Review of the Literature
}

\author{
Silvia Irina Briganti (D), ${ }^{1}$ Anda Mihaela Naciu $(\mathbb{D}),{ }^{1}$ Gaia Tabacco $\left(\mathbb{D},{ }^{1}\right.$ Roberto Cesareo $(\mathbb{D}){ }^{2}$ \\ Nicola Napoli $\mathbb{D}^{1},{ }^{1}$ Pierpaolo Trimboli $\left(\mathbb{D},{ }^{3}\right.$ Marco Castellana $\mathbb{D}^{4},{ }^{4}$ Silvia Manfrini $\mathbb{D}^{1},{ }^{1}$ \\ and Andrea Palermo ${ }^{1}{ }^{1}$ \\ ${ }^{1}$ Unit of Endocrinology and Diabetes, University Campus Bio-Medico, Rome, Italy \\ ${ }^{2}$ Unit of Metabolic Diseases, Department of Internal Medicine, S. Maria Goretti Hospital, 04100 Latina, Italy \\ ${ }^{3}$ Scienza Biomediche, Università Della Svizzera Italiana (USI), Lugano, Switzerland \\ ${ }^{4}$ Population Health Unit, National Institute of Gastroenterology "Saverio de Bellis", Research Hospital, Bari, Italy
}

Correspondence should be addressed to Andrea Palermo; a.palermo@unicampus.it

Received 2 April 2020; Revised 30 December 2020; Accepted 5 January 2021; Published 15 January 2021

Academic Editor: Arturo Bevilacqua

Copyright (c) 2021 Silvia Irina Briganti et al. This is an open access article distributed under the Creative Commons Attribution License, which permits unrestricted use, distribution, and reproduction in any medium, provided the original work is properly cited.

\begin{abstract}
Despite the large number of patients worldwide being on proton pump inhibitors (PPIs) for acid-related gastrointestinal disorders, uncertainty remains over their long-term safety. Particularly, the potential side effects of these drugs on bone health have been evaluated in the last years. The purpose of our narrative review is to gather and discuss results of clinical studies focusing on the interactions between PPIs and fracture risk. Data generated mainly from nested case-control studies and meta-analysis suggest that long-term/high-dose PPIs users are characterized by an increased risk of fragility fractures, mainly hip fractures. However, in these studies, the PPIs-induced bone impairment is often not adjusted for different confounding variables that could potentially affect bone health, and exposure to PPIs was reported using medical prescriptions without adherence evaluation. The mechanisms of the PPI-related bone damage are still unclear, but impaired micronutrients absorption, hypergastrinemia, and increased secretion of histamine may play a role. Clinicians should pay attention when prescribing PPIs to subjects with a preexistent high risk of fractures and consider antiosteoporotic drugs to manage this additive effect on the bone. However, further studies are needed to clarify PPIs action on the bone.
\end{abstract}

\section{Introduction}

Proton pump inhibitors (PPIs) are a class of medications frequently prescribed all around the world. Esomeprazole became one of the most prescribed drugs, in consequence to the high number of diagnosis of gastrointestinal disorders as gastroesophageal reflux disease and peptic ulcers [1]. In the class of PPIs, considering the releases on the pharmaceutical market, it is possible to identify different molecules that share the common capability in reducing gastric acid secretion. PPIs act by irreversibly blocking the hydrogen/potassium adenosine triphosphatase enzyme system (the $H+/ K+$ ATPase or the gastric proton pump) of the gastric parietal cells, which make the secretion of $H+$ ions in the gastric lumen possible [2]. The PPIs are given in an inactive and lipophilic form, which reaches cell cytoplasm crossing cell membranes. In an acid environment, the inactive drug is protonated and rearranges into its active form, linking covalently and irreversibly to the gastric proton pump, deactivating it. The proton pump represents the ideal target for inhibiting acid secretion because of its leading role in creating an acid environment in the stomach; as a result, PPIs are extremely effective in reducing the pain from indigestion and heartburn. However, stomach acids are necessary to absorb calcium, proteins, vitamin $B_{12}$, drugs, and other nutrients. Therefore, in conditions of prolonged hypochlorhydria, their absorption can result in impairment. 
The aim of our narrative review is to gather and discuss results of clinical studies focusing on the interactions between PPIs and fracture risk.

\section{Methods}

We searched for articles published on PubMed, EMBASE, and the Cochrane Library from inception up to December 2020, according to PRISMA guidelines [3,4] to identify published original articles and meta-analyses concerning PPIs and bone health. In particular, we searched for articles that investigated the effects of PPIs on fracture risk. The following keywords were searched: proton pump inhibitors or PPIs, lansoprazole, omeprazole, rabeprazole, pantoprazole, esomeprazole, osteoporosis, bone turnover markers, BMD, fracture, falls, osteoblast, and osteoclast.

We searched for articles published in English and those involving human participants. At the same time, we handsearched the reference lists of the retrieved articles or metaanalyses to identify additional relevant studies. To minimize differences, studies were included if they met the following criteria: (1) those that were cohort studies, case-control studies, cross-sectional studies, randomized controlled studies, or meta-analysis, (2) the exposure of interest was PPIs use and the outcomes were fractures. Exclusion criteria included nonprimary research, review articles, lack of an outcome related to the relationship between PPIs and bone health, abstract-only publications, or non-English language publications. Additional exclusion criteria for full-texts included pediatric population, case reports, and specific conditions recognized to negatively affect bone health, such as stroke, Alzheimer's, hemodialysis, and kidney transplant. Two investigators (AP and AMN) independently searched papers, screened titles, and abstracts of the retrieved articles, reviewed the full-texts, and selected articles for their inclusion. In case of disagreement, definitive reporting was achieved by mutual consensus.

A total of 1,256 studies were found through PubMed, 1,434 through Embase, and 438 through Cochrane, and after removal of all duplicates, 1,314 articles were analyzed for title and abstract; 1,145 records were excluded (reviews, letters, commentaries, posters, case reports; interventions not in humans, studies including pediatric population, or assessing specific conditions recognized to negatively affect the bone health). The remaining 169 studies were retrieved in fulltext, and 25 articles corresponding to 18 case-control studies, 6 meta-analyses, and one retrospective evaluation using an aggregated knowledge-enhanced database (Administration Adverse Event Reporting System Data Mining Set) were finally included in the review (Figure 1). No additional study was retrieved from references of included studies.

\section{Potential Mechanisms of PPIs Induced Fracture Risk}

PPIs, histamine antagonists, and other antiacid medications have improved the quality of life of patients affected by many gastrointestinal disorders. It has been demonstrated that a chronic use of PPIs is associated with potential adverse drug events, such as hypomagnesaemia, interstitial nephritis, and iron and vitamin B12 malabsorption [5]. During the past 10 years, the relationship between PPIs and bone health (Figure 2) has received attention from many investigators. In particular, PPIs seem to be associated with an increased risk of osteoporotic fractures [6], with a primary potential mechanism involving the physiological effects of chronic acid suppression on calcium, magnesium, and parathyroid hormone (PTH) metabolism [5]. The effect of PPI on bone cells has not been widely described, and available findings are limited and sometimes controversial [7-11]. In general, PPI may cause dose-dependent inhibitory effects on osteoclastic and osteoblastic human cells leading to a kind of low bone turnover syndrome. Therefore, PPI-related bone fragility might be determined by the impairment of the repair mechanisms for bone microfractures that occur daily. However, PPIs use does not appear to determine significant bone quality impairment [12].

3.1. Calcium Absorption. Calcium carbonate, one of the most common dairy calcium salts, is maximally absorbed when administrated together with a meal. Indeed, it is routinely suggested to take calcium carbonate supplements with food [13]. The acidic gastric environment stimulates the release of ionized calcium from insoluble calcium salts. Despite calcium salts precipitate in the small intestine, some calcium ions can be found in solution too. In human subjects with physiological acid secretion, insoluble calcium salts, mainly if taken after a meal, are very well absorbed as soluble calcium salts [14]. Otherwise, in hypo or achlorhydric patients, the absorption of insoluble calcium salts such as calcium carbonate, in fasting conditions, virtually does not occur, while soluble calcium salts such as calcium citrate are still absorbed normally [15]. PPIs, enhancing gastric $\mathrm{pH}$, could interfere with calcium absorption. It can lead to a negative calcium balance with consequent secondary hyperparathyroidism and increased bone loss [5, 16, 17]. Chonan et al. in an animal in vivo evaluation showed that rats on omeprazole therapy presented calcium malabsorption, and the reduction of intestinal $\mathrm{pH}$ with dietary lactate prevented the calcium absorption in rats fed with omeprazole [18]. In humans, O'Connell et al. confirmed that, in a population of $\geq 65$ years old women, a daily omeprazole dose of $20 \mathrm{mg}$ significantly reduced fasting absorption of calcium carbonate after only 7 days of treatment [19]. Moreover, impaired calcium absorption has been observed in patients after gastrectomy [20]. However, few studies in this field show controversial results.

Serfaty-Lacrosniere et al. reported that, among young healthy subjects, omeprazole therapy did not reduce the absorption of calcium contained in milk and cheese, probably in consequence to the "meal effect" and to the high bioavailability of calcium salts in these foods [21]. Hansen et al. confirmed that, in a population of postmenopausal women in therapy with omeprazole, after one month of treatment, there were not any observed differences in the absorption of calcium ingested with a meal [22]. Finally, 


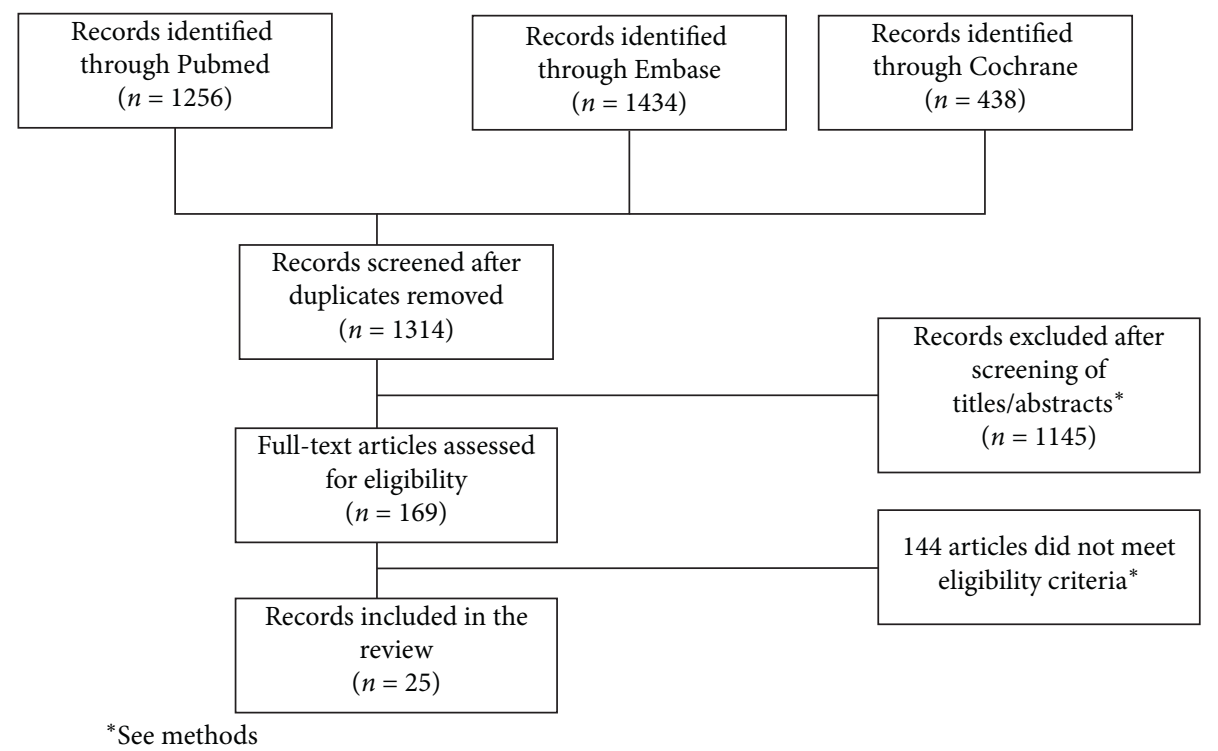

Figure 1: Study selection process.

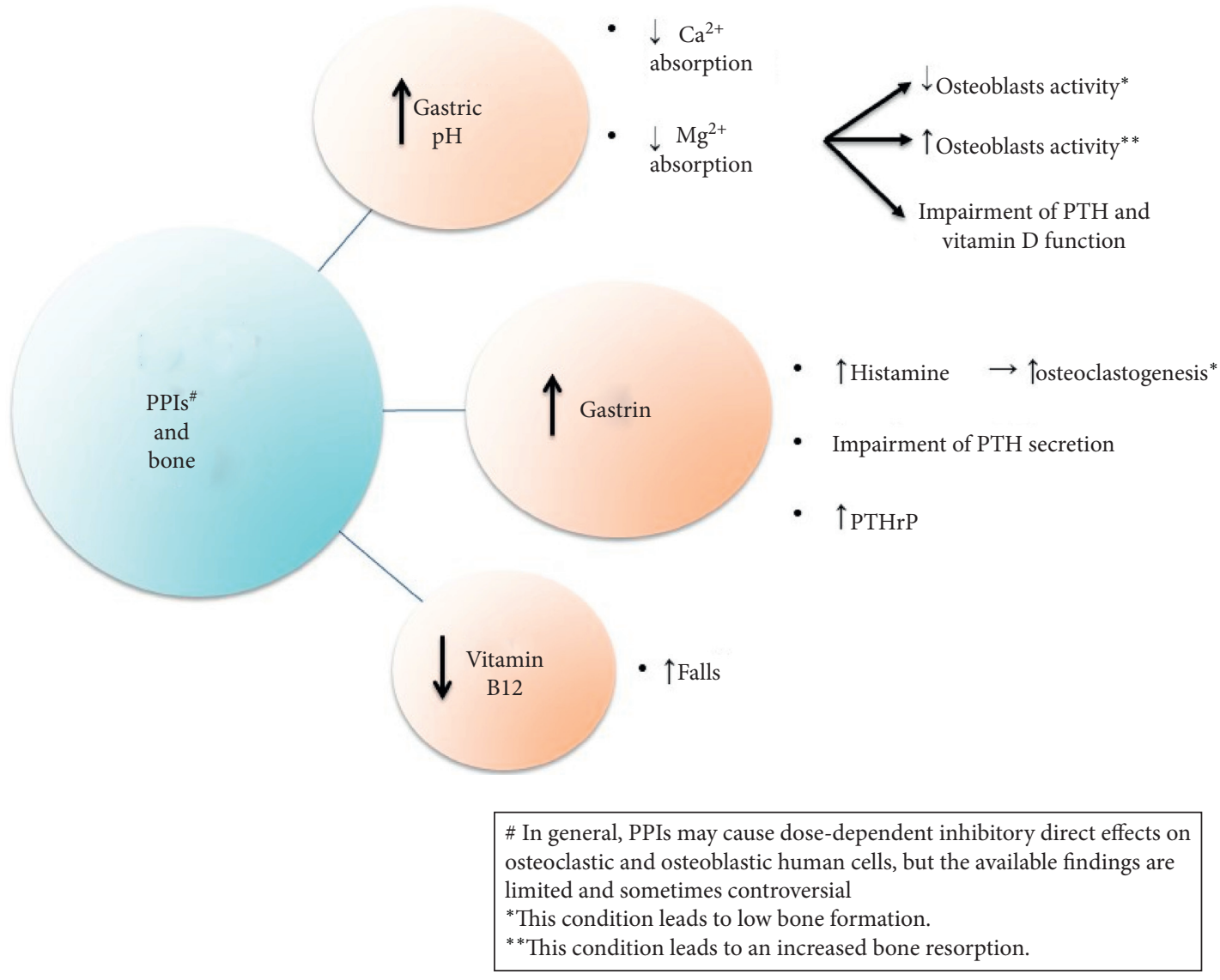

Figure 2: Potential mechanisms of PPIs induced fracture risk.

Wright et al. did not find any differences between calcium absorption or urinary calcium excretion on 12 healthy volunteers, with or without a three-day therapy with omeprazole $20 \mathrm{mg}$ twice per day enrolled in a placebocontrolled, double-blind, crossover study [23].
3.1.1. Summary. PPIs increase gastric $\mathrm{pH}$, and most of the evidences seem to confirm that they may negatively affect the calcium absorption. The controversial results of some studies can be related to short-term or low-dose PPIs therapy. 
3.2. Hypergastrinemia. More recently, research has focused its attention on PPIs' relationship with osteoclasts and PTH, the most important calcium-regulating hormone, responsible for maintaining stable calcium concentrations [5]. PTH stimulates bone resorption, increases renal tubular calcium resorption and, through the action of calcitriol, enhances the upper intestine calcium reabsorption [15]. PPIs inhibit $\mathrm{HCl}$ secretion in the gastric lumen causing a significant increase in gastric $\mathrm{pH}$, a reduction in somatostatin release from mucosal D cells located in the gastric antrum, and in consequence, an increase in serum gastrin levels. Somatostatin and gastrin act in balance one with the other, so that antiacid medications indirectly cause hypergastrinemia by suppressing somatostatin release. PPIs are excreted by the kidney, so that their compensatory hypergastrinemia appears higher in patients with impaired kidney function in consequence of a reduced drug clearance [24]. Patients in therapy with PPIs present a 2-6-fold increase in serum gastrin in comparison with control subjects [25], especially during the first months of treatment, with a progressive plateau [26]. Enhanced levels of gastrin, responsible for an enterochromaffin-like cells (ECL cells) hyperplasia, induce histamine secretion. Histamine links to receptors localized on mature and precursor osteoclasts promote osteoclastogenesis and bone resorption [27]. However, to date, there are no in vivo human studies that have investigated the impact of hypergastrinemia-induced histamine secretion on bone health. According to this concept, an observational study suggested that the blockage of type 1 histamine receptors on osteoclasts with an $\mathrm{H} 1$ receptor antagonist may reduce the risk of hip fractures (adjusted OR: 0.86, 95\% CI 0.79-0.93), regardless of PPIs use [28]. Moreover, hypergastrinemia has been shown to have a stimulatory effect on the parathyroid glands. In vivo animal studies demonstrated that omeprazole-induced hypergastrinemia was associated with hyperparathyroidism, with an increase in parathyroid gland volume and weight, and consequent osteopenia [29]. Similar outcomes were obtained in chickens after 5 weeks of omeprazole administration with a resulting hyperplasia and hypertrophy of the parathyroid glands, an increased PTH gene expression and a reduction in femur density [30]. As a proof that all these modifications recognize hypergastrinemia as the major cause, a direct infusion of gastrin increased the weight of the parathyroid glands and reproduced the effect of omeprazole on PTH gene expression in the same animal model [31]. There are only a few in vivo human studies on this topic, and the findings are contrasting [32]. An earlier publication demonstrated that, in subjects with primary hyperparathyroidism, PTH does not affect gastrin levels and that chronic moderate hypercalcemia does not raise serum fasting gastrin, at least in clinical conditions [33]. Instead, Zaniewski and colleagues demonstrated that chronic hypercalcemia of either parathyroid or nonparathyroid origin may elevate serum gastrin concentrations [34]. Moreover, a few evidence support the hypothesis that gastrin may positively regulate parathyroid hormone-related peptide (PTHrP) expression [35].
3.2.1. Summary. PPI-induced hypergastrinemia stimulates histamine and might enhance PTH secretion that may promote osteoclastogenesis and bone resorption. Few in vivo animal and human studies seem to confirm these findings.

3.3. Hypomagnesaemia. PPIs use may be associated with hypomagnesaemia [5]. In particular, a dose response between the PPIs use and development of hypomagnesaemia has been described in literature [36]. Magnesium is an oligoelement involved in bone metabolism both directly and indirectly. Several studies in vitro [37] and in human [38] and animal [39] models have demonstrated that magnesium deficiency reduces osteoblastic activity, detected through the measurement of alkaline phosphatase and osteocalcin, and proliferation. An increase in the number of osteoclasts in conditions of low magnesium levels has also been observed [40]. The imbalance between osteoblastic and osteoclastic differentiation should be likely determined by an enhanced activity of the nitric oxide synthase promoted in the condition of hypomagnesaemia [41]. Furthermore, nitric oxide results involved in bone marrow vasculature modifications, responsible for low magnesium induced-endothelial dysfunction, contribute to the decline of bone mass [42]. In addition to these mechanisms, magnesium deficiency affects bone homeostasis interfering with PTH and vitamin D function [43]. Studies in vitro demonstrated that acute changes in magnesium levels affects PTH secretion (an acute decrease in magnesium concentration increases PTH secretion and vice-versa) [44]. Moreover, in vivo studies have shown that hypomagnesaemia impairs PTH secretion and makes target organs refractory to PTH. PTH signaling involves the adenylate cyclase enzyme, which requires $\mathrm{Mg}$ as a cofactor [45]. Similarly, 25-hydroxycholecalciferol-1-hydroxylase requires $\mathrm{Mg}$ to promote the hydroxylation of vitamin $\mathrm{D}$ intermediates, so that magnesium deficiency could reduce the activity of these two different enzymatic pathways [46]. Finally, hypomagnesaemia promotes oxidative stress, inducing the production of free radicals and cytokines such as TNF $\alpha$, IL-1s, and IL-6 [47], which stimulate osteoclast activity and differentiation [48], contributing to the imbalance between osteoblasts and osteoclasts [49].

3.3.1. Summary. PPI-induced hypomagnesaemia may determine the imbalance between osteoblasts and osteoclasts, interferes with the hydroxylation of vitamin D intermediates, and makes target organs (renal and bone) resistant to PTH action.

3.4. Increased Falls. Another proposed mechanism that could explain the increase in fracture risk with chronic PPIs use is the increased rate of falls. Indeed, PPIs determine vitamin B12 deficiency in consequence to malabsorption [50]. One prospective cohort study found that patients treated with PPIs were more at risk to have deficient vitamin B12 levels compared to those not treated with a PPIs. Furthermore, in this study, patients treated with PPIs 
reported numbness of the feet and visual disturbances, a side effect of vitamin B 12 deficiency, which can certainly contribute to an increased risk of falling [51]. A case-control study enrolling 64,399 elderly Swedish patients hospitalized for a fall evidenced that the use of acid suppression drugs caused an increased risk of falling [52]. In addition, Lewis et al. in a large prospective cohort of postmenopausal elderly women found that a continuative therapy with PPIs for 1 year or more was associated with an increased risk of falls and fracture-related hospitalizations. This study also found that patients treated with long-term PPIs had an increased risk of self-reported falling (adjusted OR: 1.51, 95\% CI $1.00-2.27)[53]$.

3.4.1. Summary. PPI-induced vitamin B12 deficiency may lead to an increased rate of falls with the consequent increased risk of fractures.

3.5. PPIs and BMD. Some authors have investigated the relationship between PPIs and BMD changes, but literature offers contrasting results.

A prospective evaluation showed that after 12 months, subjects using PPIs, in particular, esomeprazole, had lower femur neck and total hip BMD T scores [54]. In a large nested case-control study published in 2010, PPIs were associated with a marginal effect on 3-year BMD change at the hip $(0.74 \%, 95 \%$ CI (0.01-1.51)) but not at other skeletal sites [55]. In accordance with these previous studies, other cross-sectional evaluations showed that PPIs users had higher rates of osteoporosis at hip than controls $[56,57]$.

However, the association between PPIs use and hip fracture is probably related to factors partially independent of low bone mass. In fact, some cross-sectional $[53,58]$ and longitudinal evaluations [58-61] showed that PPIs use does not seem to be associated with BMD loss. These findings are supported by two recent meta-analyses $[62,63]$.

3.5.1. Summary. PPIs users might not be associated with an increased femoral bone loss, but findings are not conclusive.

3.6. PPIs and Risk of Fractures. The characteristics of the included studies are provided in Table 1. Studies regarding risk of fracture and PPIs included in this review were all case-control studies and have been published from 2006 to 2020. No randomized controlled study was found. A great heterogeneity exists among the studies. Different PPIs were used, and some studies did not specify the type and dosage. Heterogeneity between studies was also noted for age, and the sample size ranged from 261 to 192,028 PPIs users. There was a high variability in the exclusion of comorbidities that can affect bone health. In addition, 8 studies $(40 \%$ of the included studies) did not adjust the fracture risk for major confounding factors, such as BMD. The minimum length of PPIs exposure was at least one prescription. Great differences in the follow-up time were further sources of heterogeneity.
Focusing on hip fractures, in 2006, Yang et al. conducted a case-control study showing that long-term PPIs therapy exposes users to an increased risk of hip fracture. In particular, the risk significantly increased among patients on long-term and high-dose PPIs (OR: 2.65, 95\% CI 1.80-3.90) [64]. In accordance with previous findings, in 2014, Cea Soriano et al. highlighted that PPIs' use modestly increased risk of hip fracture (OR: 1.09, 95\% CI 1.01-1.17) [68]. When compared to H2-receptor antagonists (H2RA), the initiation of PPIs seems to be associated with a higher risk of hip fracture (HR: 1.27, 95\% CI 1.09-1.48) [78].

However, evidences reported an increased risk of fractures also at nonfemoral sites $[69,81]$. In particular, Vestergaard et al. investigated the effects of one-year therapy with PPIs on fracture risk. They demonstrated that the use of PPIs not only increased the risk of hip fracture (OR: 1.45, 95\% CI 1.28-1.65) but also of fractures at spine (OR: 1.60, 95\% CI 1.25-2.04) and at any skeletal sites (OR: 1.18, 95\% CI 1.12-1.43) [65]. In 2010, Gray performed a nested casecontrol study on 130,487 women with a follow-up of 7.8 years. After multivariate analysis, the risk for the spine (HR: 1.47, 95\% CI 1.18-1.82), lower arm/wrist (HR: 1.26, 95\% CI $1.05-1.51$ ), or all site (HR: $1.25,95 \%$ CI 1.15-1.36) fractures resulted increased, but this finding was not observed in hip (HR: 1.00, 95\% CI 0.71-1.40) [55].

The PPIs-induced fracture risk seems to be confirmed also after adjusting the analysis for multiple risk factors, including femoral neck bone density and use of bisphosphonates (BP) (HR: 1.40, 95\% CI 1.11-1.77). [66]. The impairment of bone health has been shown in both Caucasian [70] and Asian cohorts [67, 75, 77]. In particular, Lee et al. described the increase risk of hip fractures in PPIs users/BP nonusers in comparison with PPIs/BP nonusers in a large cohort of Korean subjects (OR: 1.34, 95\% CI 1.24-1.44). However, the risk was not dose and/or drugdependent in PPIs users/BP nonusers [67]. Very recently, in another cohort of Korean population, Park et al. evaluated 8,903 elderly women suffering osteoporotic fractures and 44,515 matched controls without fractures between 2009 and 2015. Short- and long-term PPIs use showed a positive association with the risk of osteoporotic fracture (OR: 1.3, 95\% CI $1.09-1.56$ and OR: $1.31,95 \%$ CI $1.23-1.38$, respectively), and cumulative dose did not show any influence over fracture risk [75].

PPIs use would negatively affect the fracture risk also in men. In particular, Adams et al. confirmed the relationship between the dose and duration of PPIs use and hip fracture risk in 7,000 nonHispanic Caucasian men (long use-OR: 1.23, 95\% CI 1.02-1.48; recent use-OR: 1.22 , 95\% CI $1.02-1.47)$ [71].

In the last years, some meta-analyses have investigated the impact of PPIs use on the development of fragility fractures. The authors concluded that PPIs use may be associated with an increased risk of hip $[62,82,83]$ and anysite fracture $[63,84,85]$.

PPIs seem also to increase the risk of refractures in elderly population. In particular, Brozek et al. analyzed retrospectively the impact of PPIs use on the risk of hip refracture in a population of 31,668 patients who suffered 
TABLE 1: Main characteristics of studies regarding PPIs and risk of fractures.

\begin{tabular}{|c|c|c|c|c|c|c|c|}
\hline Author [Ref] & Year & Study design & Aim of the study & Study population & Intervention & Main findings & Main limitations \\
\hline $\begin{array}{l}\text { Yang et al. } \\
{[64]}\end{array}$ & 2006 & $\begin{array}{l}\text { Nested case- } \\
\text { control study }\end{array}$ & $\begin{array}{l}\text { To explore the } \\
\text { association } \\
\text { between PPIs } \\
\text { therapy and risk of } \\
\text { hip fracture. }\end{array}$ & $\begin{array}{c}\text { 192,028 PPIs users, } \\
\text { 187,686 users of } \\
\text { H2RA, and } 1.4 \\
\text { million acid } \\
\text { suppression } \\
\text { nonusers older } \\
\text { than } 50 \text { yrs }\end{array}$ & $\begin{array}{l}\text { PPIs use }>1 \text { year } \\
\text { before hip } \\
\text { fracture. Daily } \\
\text { dosages were } \\
\text { divided in high } \\
\text { and low dosage. }\end{array}$ & $\begin{array}{l}\text { After adjustment } \\
\text { for some } \\
\text { potential } \\
\text { confounding } \\
\text { factors } \\
\text { (comorbidities } \\
\text { and drugs), long- } \\
\text { term PPIs } \\
\text { therapy, } \\
\text { particularly at } \\
\text { high doses, is } \\
\text { associated with } \\
\text { an increased risk } \\
\text { of hip fracture } \\
\text { (OR: } 2.65,95 \% \text { CI } \\
1.80-3.90 \text { ) }\end{array}$ & $\begin{array}{l}\text { Authors did not } \\
\text { adjust the results } \\
\text { for major } \\
\text { confounding } \\
\text { factors that can } \\
\text { affect bone health } \\
\text { such as BMD. } \\
\text { The study was not } \\
\text { designed to define } \\
\text { the mechanisms } \\
\text { between PPIs } \\
\text { therapy and the risk } \\
\text { of fracture. } \\
\text { Data about calcium } \\
\text { supplementation } \\
\text { were not available. }\end{array}$ \\
\hline $\begin{array}{l}\text { Vestergaard } \\
\text { et al. [65] }\end{array}$ & 2006 & $\begin{array}{c}\text { Case-control } \\
\text { study }\end{array}$ & $\begin{array}{l}\text { To evaluate the } \\
\text { effect of PPIs, } \\
\text { H2RA, and other } \\
\text { types of antacid } \\
\text { drugs on fracture } \\
\text { risk }\end{array}$ & $\begin{array}{l}124,655 \text { subjects } \\
\text { with any fracture } \\
\text { sustained during } \\
\text { the year } 2000 \text { and } \\
373,962 \text { controls }\end{array}$ & $\begin{array}{c}\text { PPIs, H2RA, } \\
\text { and other types } \\
\text { of antacid drugs }\end{array}$ & $\begin{array}{l}\text { For less than } 1 \\
\text { year since the last } \\
\text { use of PPIs, an } \\
\text { increased risk of } \\
\text { fracture was } \\
\text { registered (OR: } \\
1.18,95 \% \text { CI } \\
1.12-1.43 \text { ). }\end{array}$ & $\begin{array}{l}\text { For more than } 1 \\
\text { year since the last } \\
\text { use, the risk } \\
\text { disappeared for } \\
\text { PPIs } \\
\text { Authors did not } \\
\text { adjust the results } \\
\text { for major } \\
\text { confounding } \\
\text { factors that can } \\
\text { affect bone health. } \\
\text { Information } \\
\text { regarding BMD, } \\
\text { smoking, physical } \\
\text { activity, the use of } \\
\text { calcium or vitamin } \\
\text { D supplements, sun } \\
\text { exposure, or risk of } \\
\text { falling were not } \\
\text { available. }\end{array}$ \\
\hline
\end{tabular}


Table 1: Continued.

\begin{tabular}{|c|c|c|c|c|c|c|c|}
\hline Author [Ref] & Year & Study design & Aim of the study & Study population & Intervention & Main findings & Main limitations \\
\hline Gray [55] & 2010 & $\begin{array}{l}\text { Nested case- } \\
\text { control study }\end{array}$ & $\begin{array}{l}\text { To evaluate the } \\
\text { association of PPIs } \\
\text { use with BMD } \\
\text { changes and } \\
\text { fractures }\end{array}$ & $\begin{array}{c}161,806 \\
\text { postmenopausal } \\
\text { women }(50-79 \\
\text { years): } 3,396 \text { PPI } \\
\text { users }\end{array}$ & $\begin{array}{l}\text { PPIs use with a } \\
\text { mean follow-up } \\
\text { of } 7.8 \text { years. }\end{array}$ & $\begin{array}{c}\text { After adjustment } \\
\text { for major } \\
\text { potential } \\
\text { confounding } \\
\text { factors } \\
\text { (comorbidities } \\
\text { and drugs), PPIs } \\
\text { use was not } \\
\text { related to risk for } \\
\text { hip fracture but } \\
\text { was related to } \\
\text { clinical spine } \\
\text { (HR: } 1.47,95 \% \text { CI } \\
1.18-1.82 \text { ), lower } \\
\text { wrist/arm (HR: } \\
1.26,95 \% \text { CI } \\
1.05-1.51 \text { ), and } \\
\text { total fractures } \\
\text { (HR: } 1.25,95 \% \text { CI } \\
1.15-1.36 \text { ). A } \\
\text { marginal effect } \\
\text { on } 3 \text { years BMD } \\
\text { change at hip was } \\
\text { associated with } \\
\text { PPIs use. }\end{array}$ & $\begin{array}{l}\text { fractures. } \\
\text { Lack of information } \\
\text { on dose of PPIs } \\
\text { drugs. }\end{array}$ \\
\hline $\begin{array}{l}\text { Fraser et al. } \\
{[66]}\end{array}$ & 2013 & $\begin{array}{l}\text { Nested case- } \\
\text { control study }\end{array}$ & $\begin{array}{c}\text { To investigate if } \\
\text { PPIs use increased } \\
\text { the risk of fragility } \\
\text { fractures }\end{array}$ & $\begin{array}{l}\text { 9,423 participants } \\
\text { in the Canadian } \\
\text { Multicenter } \\
\text { Osteoporosis } \\
\text { Study: } 261 \text { PPIs } \\
\text { users }\end{array}$ & $\begin{array}{c}\text { PPIs use with a } \\
\text { follow-up of } 10 \\
\text { years }\end{array}$ & $\begin{array}{l}\text { After adjustment } \\
\text { for major } \\
\text { potential } \\
\text { confounders } \\
\text { factors, PPIs use } \\
\text { was associated } \\
\text { with a shorter } \\
\text { time to first } \\
\text { fragility fracture } \\
\text { (HR: } 1.40,95 \% \\
\text { CI } 1.11-1.77 \text { ). }\end{array}$ & $\begin{array}{c}\text { PPIs drug use data } \\
\text { only for years } 0,5 \text {, } \\
\text { and } 10 \text { of the study } \\
\text { (lack of information } \\
\text { between these time } \\
\text { points). } \\
\text { PPIs dose was not } \\
\text { accounted in this } \\
\text { study. }\end{array}$ \\
\hline Lee et al. [67] & 2013 & $\begin{array}{l}\text { Nested case- } \\
\text { control study }\end{array}$ & $\begin{array}{l}\text { To evaluate the } \\
\text { relation between } \\
\text { PPIs and risk of hip } \\
\text { fractures and to } \\
\text { explore the } \\
\text { interaction } \\
\text { between PPIs and } \\
\text { BPs }\end{array}$ & $\begin{array}{c}24,710 \text { cases of } \\
\text { incident hip } \\
\text { fractures }(1,282 \\
\text { PPIs users) and } \\
98,642 \\
\text { controls }>65 \text { years } \\
\text { old identified from } \\
\text { January } 2005 \text { to } \\
\text { June } 2006\end{array}$ & $\begin{array}{l}\text { PPIs use: at least } \\
\text { one } \\
\text { prescription of } \\
\text { PPI between } \\
2005 \text { and the } \\
\text { index date. }\end{array}$ & $\begin{array}{c}\text { Elderly subjects } \\
\text { using PPIs } \\
\text { presented an } \\
\text { increased risk of } \\
\text { hip fracture (OR: } \\
\text { 1.34, 95\% CI } \\
1.24-1.44) \text {. } \\
\text { Subjects using BP } \\
\text { and with a } \\
\text { current use or } \\
\text { high cumulative } \\
\text { dose of PPIs had a } \\
\text { higher risk of hip } \\
\text { fractures. }\end{array}$ & $\begin{array}{c}\text { Current medication } \\
\text { was reported using } \\
\text { prescriptions (also } \\
\text { subjects with only } 1 \\
\text { prescription were } \\
\text { enrolled). } \\
\text { Authors did not } \\
\text { rule out all the } \\
\text { condition that can } \\
\text { affect bone health } \\
\text { such as the } \\
\text { utilization of drugs, } \\
\text { low BMI, alcohol } \\
\text { consumption, and } \\
\text { smoking. }\end{array}$ \\
\hline
\end{tabular}


TABle 1: Continued.

\begin{tabular}{|c|c|c|c|c|c|c|c|}
\hline Author [Ref] & Year & Study design & Aim of the study & Study population & Intervention & Main findings & Main limitations \\
\hline $\begin{array}{l}\text { Cea Soriano } \\
\text { L. et al. [68] }\end{array}$ & 2014 & $\begin{array}{l}\text { Nested case- } \\
\text { control study }\end{array}$ & $\begin{array}{l}\text { To evaluate the } \\
\text { association } \\
\text { between hip } \\
\text { fracture risk and } \\
\text { use of PPIs }\end{array}$ & $\begin{array}{l}10,958 \text { subjects } \\
\text { (PPI users } 2,699) \\
\text { with hip fractures } \\
\text { and } 20,000 \text { controls } \\
\text { aged } 40-89 \text { years. }\end{array}$ & $\begin{array}{l}\text { PPIs use with a } \\
\text { mean follow-up } \\
\text { of } 5.5 \text { years }\end{array}$ & $\begin{array}{l}\text { Use of medium- } \\
\text { high dose of PPIs } \\
\text { (in particular, } \\
\text { omeprazole) was } \\
\text { associated with a } \\
\text { modest increased } \\
\text { risk of hip } \\
\text { fracture after } \\
\text { adjustment for } \\
\text { major potential } \\
\text { confounders } \\
\text { (including the } \\
\text { presence of } \\
\text { osteoporosis) } \\
\text { (high dose OR: } \\
1.31,95 \% \text { CI } \\
1.06-1.61 \text { ). }\end{array}$ & $\begin{array}{l}\text { Information about, } \\
\text { family history, diet, } \\
\text { and physical } \\
\text { activity were not } \\
\text { available. }\end{array}$ \\
\hline
\end{tabular}

Authors did not rule out some major conditions that can affect bone health. Information about $\mathrm{BMD}$, calcium and vitamin $\mathrm{D}$ intake, physical activity, and alcohol use

Subjects with higher adherence at PPIs therapy

To evaluate the relationship

Ding et al. [69]

Nested casecontrol study between PPIs use/ adherence and fracture risk among
1,604 PPIs users and 23,672

nonusers $(>65$ years old)
PPIs use with a follow-up of 5 years were associated

with grater fracture risk after adjustment for some potential confounders (HR: 1.27, 95\% CI $1.12-1.43)$.

were not available.

Adherence to treatment and fractures were

identified by using administrative

claims data.

By using diagnostic codes for incident fractures (without validation through imaging or procedure coding), some false-positive fractures might be included.

1 yr baseline period was used to exclude prior fractures and PPIs usage.

Lack of information After adjustment on duration of PPIs for major potential

To investigate risk factors at baseline Moberg et al. 2014 Nested case[70] control study for first fracture in postmenopausal women during long-term followup

\section{6,917 women $>50 \quad$ PPIs use with a years old: 121 PPIs}

users mean follow-up
of 14.4 years confounding

factors, the use of PPIs was associated with a doubled risk of fracture (OR: 2.53, $95 \%$ CI $1.28-4.99)$. use.

The baseline information was self-reported.

Clinical vertebral fractures were undiagnosed, and the true number of fractures might be higher than reported. 
TABle 1: Continued.

\begin{tabular}{|c|c|c|c|c|}
\hline Author [Ref] & Year & Study design & Aim of the study & Study population \\
\hline $\begin{array}{l}\text { Adams et al. } \\
{[71]}\end{array}$ & 2014 & $\begin{array}{l}\text { Nested case- } \\
\text { control study }\end{array}$ & $\begin{array}{l}\text { To estimate the } \\
\text { association } \\
\text { between PPIs use } \\
\text { and hip fracture }\end{array}$ & $\begin{array}{l}6,774 \text { men with a } \\
\text { hip fracture ( } 896 \\
\text { used omeprazole } \\
\text { and } 694 \text { used } \\
\text { pantoprazole) and } \\
6,774 \text { controls } \\
\text { aged } \geq 45 \text { years old }\end{array}$ \\
\hline
\end{tabular}

Intervention
PPIs use
(omeprazole
and
pantoprazole)
with a follow-up
of 10 years

Main findings
Most adherent,
long-term (OR:

$1.02-1.48)$ or

most recent (OR:

1.22, 95\% CI

1.02-1.47) PPIs

users (men)

presented an

increased risk of

hip fracture

Main limitations

Authors did not

adjust the results

for major

confounding

factors that can

affect bone health,

such as BMD.

Pharmacy records are limited to dispensed prescriptions.

Residual confounding factors such as vitamin $\mathrm{B} 12$ deficiency, celiac disease, and lower

PPIs use is associated with

To evaluate the effect of dose and

Van der

Hoorn et al. 2015 Nested case[72] type of PPIs use on subsequent use of osteoporosis drugs and fractures in older Australian women
4,432 women $>77 \quad$ PPIs use with an years old $(2,328$ PPIs users)
PPIs use with an
average followup of $6.6 \mathrm{yrs}$ an increased risk of the subsequent

use of

osteoporosis medication (HR: $1.28,95 \%$ CI 1.13-1.44) and fractures (HR: $1.29,95 \% \mathrm{CI}$ $1.08-1.55)$ in older women dose of corticosteroids were not included in this study. Lack of information on compliance with PPIs use.

The fractures outcome was based only on hospital admission data.

Self-reported chronic conditions. Exposure to PPIs was reported using prescriptions (also subjects with only 1 prescription were enrolled).

Authors did not adjust the results for major confounding factors that can

7,208 subjects with newly diagnosed

To explore the relationship

Lai et al. [73] 2018 $\begin{aligned} & \text { Nested case- } \\ & \text { control study }\end{aligned}$ users 2,083) and (PPI 7,208 controls without fracture (PPIs users 1,776), $>65$ years old
PPIs use between PPIs and hip fracture
After adjustment for some confounding factors, no significant association was found between

PPIs use and the risk of hip fracture (OR: 0.96, 95\% CI $0.76-1.22$ ) affect bone health, such as BMD. Data on other pharmacological treatment was not available. 
TABle 1: Continued.

\begin{tabular}{|c|c|c|c|c|c|c|}
\hline Author [Ref] & Year & Study design & Aim of the study & Study population & Intervention & Main findings \\
\hline $\begin{array}{l}\text { Harding } \\
\text { et al. [74] }\end{array}$ & 2018 & $\begin{array}{l}\text { Nested case- } \\
\text { control study }\end{array}$ & $\begin{array}{l}\text { To evaluate if the } \\
\text { use of PPIs is } \\
\text { associated with an } \\
\text { increased fracture } \\
\text { risk }\end{array}$ & $\begin{array}{l}4,438 \text { participants } \\
\text { aged } \geq 65 \text { years old } \\
\text { (408 PPIs users) }\end{array}$ & $\begin{array}{l}\text { PPIs use with a } \\
\text { mean follow-up } \\
\text { of } 6.1 \text { years }\end{array}$ & $\begin{array}{l}\text { After adjustment } \\
\text { for some } \\
\text { potential } \\
\text { confounding } \\
\text { factors, older } \\
\text { adults using PPIs } \\
\text { presented no } \\
\text { increased fracture } \\
\text { risk (HR: } 1.14 \text {, } \\
\text { 95\% CI } \\
0.91-1.42 \text { ). }\end{array}$ \\
\hline
\end{tabular}

Main limitations

Authors did not

adjust the results

for major

confounding

factors that can

affect bone health,

such as BMD. Lack

of information

about alcohol use, calcium and

vitamin $\mathrm{D}$ intake, and the family

$0.91-1.42)$

history of fractures.

Diagnosis codes

were used to

ascertain fractures.

High rate of nonparticipating

Korean women.

After adjustment

for major confounding

factors, long-

8,903 subjects with

To compare the new osteoporotic risk of osteoporotic fractures $(4,301$

Park et al. [75] 2020 Nested casecontrol study fracture between

PPIs users and H2RA-only users
PPIs users) and

44,515 matched controls $>66$ years old
PPIs and H2RA use with a mean follow-up of 1.7 years

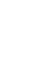

term and recent

PPIs uses have

been associated with an increased risk of osteoporotic fractures (OR: 1.31, 95\% CI: 1.23-1.38) compared with H2RA-only use.

\section{Osteoporotic}

fractures have been ascertained without reviewing medical records and imaging data.

Not all traumatic

fractures have been ruled out.

The effects of PPIs in subjects with a history of fractures have not been evaluated because patients with previous fractures were excluded.

Authors did not adjust the results for major confounding factors that can not associated with an increased risk of fractures even after

To examine the

Hoff et al. [76]
Nested casecontrol study

\section{association}

between the use of PPIs and risk of fractures
28,258 subjects (4,490 PPIs users) aged 50-85 years.
Average PPIs use of $3.8 \mathrm{yrs}$ adjustment for some

confounding factors in both women (OR:

$0.80,95 \%$ CI

0.65-0.98) and men (OR: 1.00

95\% CI

0.69-1.45) affect bone health.

Lack of information about BMD,

alcohol use, calcium and vitamin $\mathrm{D}$ intake, and the family history of fractures.

Only hip and forearm fractures have been registered. 
TABle 1: Continued.

\begin{tabular}{|c|c|c|c|c|}
\hline Author [Ref] & Year & Study design & Aim of the study & Study population \\
\hline $\begin{array}{l}\text { Park et al. } \\
\text { [77] }\end{array}$ & 2020 & $\begin{array}{l}\text { Nested case- } \\
\text { control study }\end{array}$ & $\begin{array}{l}\text { To investigate the } \\
\text { risk of osteoporotic } \\
\text { fractures associated } \\
\text { with PPI use } \\
\text { compared to } \\
\text { exclusive H2RA } \\
\text { use in Korean } \\
\text { population }\end{array}$ & $\begin{array}{l}59,240 \text { subjects } \\
\text { with osteoporotic } \\
\text { fractures }(23,311 \\
\text { PPIs users) with a } \\
\text { mean age of } \\
64.8 \pm 8.0 \text { and } \\
296,200 \text { controls } \\
\text { (103,742 PPIs } \\
\text { users) }\end{array}$ \\
\hline
\end{tabular}

Intervention
Median PPIs
use of 30 days

Main findings
Use of PPIs was
associated with
an increased risk
of osteoporotic
fractures even
after adjustment
for confounding
factors (OR: 1.11 ,
$95 \%$ CI
$1.08-1.13$ )
compared to
H2RA users

To compare the

Wei et al. Propensity risk of incident hip 50,265 PPIs and [78] 2020 score-matched cohort study
Average PPIs use of $3.7 \mathrm{yrs}$ fracture between 50,265 H2RA users

PPIs and H2RA

initiators
$>50$ years old
The initiation of PPIs was

associated with a higher risk of hip fracture than the initiation of

H2RA (HR: 1.27, 95\% CI $1.09-1.48)$.

Main limitations

Residual
confounding

factors that can affect bone health.

Lack of information about BMD.

The osteoporotic fractures were

defined using the diagnostic codes of claims data

Subjects with higher PPIs prescriptions had high risk for hip fracture (OR: 1.67, 95\% CI 1.33-2.10) Authors did not adjust the results for major confounding factors that can affect bone health. Lack of information about BMD and the family history of fractures.

Lack of information about alcohol use, calcium and

To assess if the use of PPIs is 358 cases (202 PPIs

Reyes et al. Retrospective associated with an users) matched [79] 2013 case-control study increased risk of hip fracture in a Mediterranean area with 698 controls (312 PPIs users), $>50$ years old
PPIs use in the 5 years before the hip fracture

The use of PPIs was not associated with an increased risk of hip fracture after adjusting for major risk factors (including the presence of osteoporosis)

(OR 1.17, 95\% CI $0.77-1.79$ )

Low-dose PPIs use is not associated with the increased risk

To examine the

Brozek et al. [80]
2019
Retrospective cohort study association of PPIs

use with hip fracture
31,668 Austrian patients $\geq 50$ years with a first hip fracture $(13,262$ PPIs users)
PPIs use with a median followup of 1.54 years of subsequent hip

fractures (OR:

$1.35,95 \% \mathrm{CI}$

0.99-1.82), especially in women. vitamin $\mathrm{D}$ intake, and the family

history of fractures. Exposure to PPIs was reported using prescriptions (also subjects with only 1 prescription were enrolled).

Information on comorbidities and comedications except for antiosteoporotic drugs was not available.

Lack of information on BMD, calcium and vitamin $\mathrm{D}$ intake, physical activity, BMI, alcohol

consumption, and smoking.

PPIs, proton pump inhibitors; H2RA, H2-receptor antagonists; BMD, bone mineral density; BP, bisphosphonates.

hip fracture between July 2008 and December 2010 excluding antiosteoporotic users. The authors demonstrated that PPIs therapy increased the risk for subsequent hip fracture (OR: 1.58, 95\% CI 1.25-2.00), in particular in 70-84-year-old men; however, these findings were not confirmed in case of low dosage (OR: 1.35, 95\% CI 
0.99-1.82) and short-term therapy (OR: 1.14, 95\% CI 0.77-1.69) [80].

In contrast, some authors showed that PPIs do not affect the risk of fracture, regardless of ethnicity, duration of the therapy, and the dose, absolute or cumulative [73, 74, 79]. In particular, in a very recent retrospective investigation, Hoff et al. demonstrated in a Norwegian population of 15,017 women and 13,241 men, aged 50-85 years, that PPIs therapy did not expose to an increased fracture risk in either women (HR: $0.80,95 \%$ CI $0.65-0.98$ ) or men (HR: $1.00,95 \% \mathrm{CI}$ $0.69-1.45)[76]$.

3.6.1. Summary. Most evidences support that long-term high-dosage PPIs users are characterized by the increased risk of fractures.

3.7. Efficacy of Antiresorptive Agents and PPIs. Treatment of osteoporosis is aimed to prevent fragility fractures and to stabilize or increase bone mineral density [86]. It has been demonstrated that PPIs users are more likely to subsequently have osteoporosis therapy than nonusers [72], but it is not clear if PPIs can affect the efficacy of antiosteoporotic therapy in preventing fractures. A small prospective investigation [87] and a post hoc analysis of 3 RCT trials [88] reported that, regardless of PPIs concomitant use, risedronate significantly reduced the risk of new vertebral fractures compared with placebo [88] and increased the BMD $[87,88]$. Same findings have been found for the use of teriparatide [89].

As shown by Alhambra et al. and Abrahamsen et al., PPIs use might predict the occurrence of fractures independently of compliance and persistence to BP therapy [90, 91].

Moreover, a meta-analysis published by Yang et al. found that the overall fracture risk of BP and PPIs users versus only BP users was increased [92].

In contrast, there is only one prospective study conducted on osteoporotic patients using concomitant PPIs that has shown a greater increase in lumbar BMD after one year of treatment with alendronate in comparison with alfacalcidiol. However, although the design of study is adequate, the small sample size affects the data interpretation [93].

3.7.1. Summary. Poor and incomplete data do not allow providing clear clinical information on the interaction between PPIs and BPs.

\section{Conclusions}

Data generated mainly from nested case-control studies and meta-analyses suggest that long-term/high-dose PPIs users are characterized by an increased risk of fragility fractures, mainly hip fractures. However, in these studies, the PPIsinduced bone impairment is often not adjusted for different confounding variables that could potentially affect bone health, and exposure to PPIs was reported using medical prescriptions without adherence evaluation. Impairment of calcium, magnesium, and vitamin B absorbance, hypergastrinemia, an increased secretion of histamine, play an important role in determining the increased fracture risk, although the pathophysiological mechanisms of the PPIsrelated bone damage are still unclear.

Physicians should carefully evaluate the risk of fractures in long-term high-dose PPIs users and suggest adequate calcium/vitamin D supplementation. Clinicians should pay attention when prescribing PPIs to subjects with a preexistent high risk of fractures, and they may consider antiosteoporotic drugs to manage this additive effect on the bone. Antiosteoporotic drugs still remain the best option for the management of PPIs users with high risk of fracture.

However, further studies are needed to clarify PPIs' action on the bone and to estimate the real risk of fracture.

\section{Data Availability}

The data supporting this review are from previously reported studies and datasets, which have been cited.

\section{Conflicts of Interest}

The authors declare that they have no conflicts of interest.

\section{Authors' Contributions}

Silvia Irina Briganti and Anda Mihaela Naciu contributed equally to this work.

\section{References}

[1] L. Aguilera Castro, C. Martín de Argila de Prados, A. Albillos Martínez, and Albillos-Martínez, "Practical considerations in the management of proton-pump inhibitors," Revista Espanola de Enfermedades Digestivas, vol. 108, no. 3, 2015.

[2] P. Malfertheiner, A. Kandulski, and M. Venerito, "Protonpump inhibitors: understanding the complications and risks," Nature Reviews Gastroenterology and Hepatology, vol. 14, no. 12, pp. 697-710, 2017.

[3] D. Moher, A. Liberati, J. Tetzlaff, and D. G. Altman, "Preferred reporting items for systematic reviews and meta-analyses: the PRISMA statement," PLoS Medicine, vol. 6, no. 7, p. e1000097, 2009.

[4] L. Zorzela, Y. K. Loke, J. P. Ioannidis et al., "PRISMA harms checklist: improving harms reporting in systematic reviews," BMJ, vol. 352, p. i157, 2016.

[5] T. Ito and R. T. Jensen, "Association of long-term proton pump inhibitor therapy with bone fractures and effects on absorption of calcium, vitamin B12, iron, and magnesium," Current Gastroenterology Reports, vol. 12, no. 6, pp. 448-457, 2010.

[6] B. K. S. Thong, S. Ima-Nirwana, and K.-Y. Chin, "Proton pump inhibitors and fracture risk: a review of current evidence and mechanisms involved," International Journal of Environmental Research and Public Health, vol. 16, no. 9, p. 1571, 2019.

[7] M. Prause, C. Seeliger, M. Unger, M. Van Griensven, and A. T. Haug, "Pantoprazole increases cell viability and function of primary human osteoblasts in vitro," Injury, vol. 45, no. 8, pp. 1156-1164, 2014.

[8] M. Prause, C. Seeliger, M. Unger, E. Rosado Balmayor, M. Van Griensven, and A. T. Haug, "Pantoprazole Decreases 
Cell Viability and Function of Human Osteoclasts in Vitro," Injury, vol. 45, 2015.

[9] J. Costa-Rodrigues, S. Reis, S. Teixeira, S. Lopes, and M. H. Fernandes, "Dose-dependent inhibitory effects of proton pump inhibitors on human osteoclastic and osteoblastic cell activity," FEBS Journal, vol. 280, no. 20, pp. 5052-5064, 2013.

[10] K. Rzeszutek, F. Sarraf, and J. E. Davies, "Proton pump inhibitors control osteoclastic resorption of calcium phosphate implants and stimulate increased local reparative bone growth," Journal of Craniofacial Surgery, vol. 14, no. 3, pp. 301-307, 2003.

[11] A. Sheraly, D. Lickorish, F. Sarraf, and J. Davies, "Use of gastrointestinal proton pump inhibitors to regulate osteoclast- mediated resorption of calcium phosphate cements in vivo," Current Drug Delivery, vol. 6, no. 2, pp. 192-198, 2009.

[12] L. E. Targownik, A. L. Goertzen, Y. Luo, and W. D. Leslie, "Long-term proton pump inhibitor use is not associated with changes in bone strength and structure," American Journal of Gastroenterology, vol. 112, no. 1, pp. 95-101, 2017.

[13] E. T. Champagne, "Low gastric hydrochloric acid secretion and mineral bioavailability," Advances in Experimental Medicine and Biology, vol. 249, pp. 173-184, 1989.

[14] M. S. Sheikh, C. A. Santa Ana, M. J. Nicar, L. R. Schiller, and J. S. Fordtran, "Gastrointestinal absorption of calcium from milk and calcium salts," New England Journal of Medicine, vol. 317, no. 9, pp. 532-536, 1987.

[15] A. Palermo, A. M. Naciu, G. Tabacco et al., "Calcium citrate: from biochemistry and physiology to clinical applications," Reviews in Endocrine and Metabolic Disorders, vol. 20, no. 3, pp. 353-364, 2019.

[16] R. Cesareo, "Effectiveness and safety of calcium and vitamin D treatment for postmenopausal osteoporosis," Minerva Endocrinologica, vol. 40, no. 3, pp. 231-237, 2015.

[17] R. Cesareo, A. Falchetti, R. Attanasio et al., "Hypovitaminosis $\mathrm{D}$ : is it time to consider the use of calcifediol?" Nutrients, vol. 11, no. 5, p. 1016, 2019.

[18] O. Chonan, R. Takahashi, H. Yasui, and M. Watanuki, "Effect of L-lactic acid on calcium absorption in rats fed omeprazole," Journal of Nutritional Science and Vitaminology, vol. 44, no. 3, pp. 473-481, 1998.

[19] M. B. O'Connell, D. M. Madden, A. M. Murray, R. P. Heaney, and L. J. Kerzner, "Effects of proton pump inhibitors on calcium carbonate absorption in women: a randomized crossover trial," The American Journal of Medicine, vol. 118, no. 7, pp. 778-781, 2005.

[20] M. Krause, J. Keller, B. Beil et al., "Calcium gluconate supplementation is effective to balance calcium homeostasis in patients with gastrectomy," Osteoporosis International, vol. 26, no. 3, pp. 987-995, 2015.

[21] C. Serfaty-Lacrosniere, R. J. Wood, D. Voytko et al., "Hypochlorhydria from short-term omeprazole treatment does not inhibit intestinal absorption of calcium, phosphorus, magnesium or zinc from food in humans," Journal of the American College of Nutrition, vol. 14, no. 4, pp. 364-368, 1995.

[22] K. E. Hansen, A. N. Jones, M. J. Lindstrom et al., "Do proton pump inhibitors decrease calcium absorption?" Journal of Bone and Mineral Research, vol. 25, no. 12, pp. 2786-2795, Dec. 2010.

[23] M. J. Wright, R. R. Sullivan, E. Gaffney-Stomberg et al., "Inhibiting gastric acid production does not affect intestinal calcium absorption in young, healthy individuals: a randomized, crossover, controlled clinical trial," Journal of Bone and Mineral Research, vol. 25, no. 10, pp. 2205-2211, 2010.

[24] Y.-X. Yang, "Chronic proton pump inihibitor therapy and calcium metabolism," Current Gastroenterology Reports, vol. 14, no. 6, pp. 473-479, 2012.

[25] G. Brunner and W. Creutzfeldt, "Omeprazole in the longterm management of patients with acid-related diseases resistant to ranitidine," Scandinavian Journal of Gastroenterology, vol. 24, no. sup166, pp. 101-105, 1989.

[26] G. Brunner, W. Creutzfeldt, U. Harke, and R. Lamberts, "Therapy with omeprazole in patients with peptic ulcerations resistant to extended high-dose ranitidine treatment," $\mathrm{Di}$ gestion, vol. 39, no. 2, pp. 80-90, 1988.

[27] M. Biosse-Duplan, B. Baroukh, M. Dy, M.-C. De Vernejoul, and J.-L. Saffar, "Histamine promotes osteoclastogenesis through the differential expression of histamine receptors on osteoclasts and osteoblasts," The American Journal of Pathology, vol. 174, no. 4, pp. 1426-1434, 2009.

[28] B. Abrahamsen and P. Vestergaard, "Proton pump inhibitor use and fracture risk - effect modification by histamine $\mathrm{H} 1$ receptor blockade. Observational case-control study using National Prescription Data," Bone, vol. 57, no. 1, pp. 269-271, 2013.

[29] L. Grimelius, H. Johansson, G. Lundqvist, A. Olazabal, J. H. Polak, and A. G. E. Pearse, "The parathyroid glands in experimentally induced hypergastrinemia in the rat," Scandinavian Journal of Gastroenterology, vol. 12, no. 6, pp. 739744, 1977.

[30] R. Gagnemo-Persson, R. Håkanson, F. Sundler, and P. Persson, "Growth of the parathyroid glands in omeprazoletreated chickens," Scandinavian Journal of Gastroenterology, vol. 29, no. 6, pp. 493-497, 1994.

[31] R. Gagnemo-Persson, A. Samuelsson, R. Håkanson, and P. Persson, "Chicken parathyroid hormone gene expression in response to gastrin, omeprazole, ergocalciferol, and restricted food intake," Calcified Tissue International, vol. 61, no. 3, pp. 210-215, 1997.

[32] K. Mizunashi, Y. Furukawa, K. Katano, and K. Abe, "Effect of omeprazole, an inhibitor of $\mathrm{H}+, \mathrm{K}+-\mathrm{ATPase}$, on bone resorption in humans," Calcified Tissue International, vol. 53, no. 1, pp. 21-25, 1993.

[33] I. Vantini, "Fasting serum gastrin in primary hyperparathyroidism and in chronic hypercalcemia," Acta Hepatogastroenterol. (Stuttg).vol. 26, no. 6, pp. 472-477, 1979.

[34] M. Zaniewski, P. H. Jordan, B. Yip, J. I. Thornby, and L. E. Mallette, "Serum gastrin level is increased by chronic hypercalcemia of parathyroid or nonparathyroid origin," Archives of Internal Medicine, vol. 146, no. 3, pp. 478-482, 1986.

[35] A. Al Menhali, T. M. Keeley, E. S. Demitrack, and L. C. Samuelson, "Gastrin induces parathyroid hormone-like hormone expression in gastric parietal cells," American Journal of Physiology-Gastrointestinal and Liver Physiology, vol. 312, no. 6, pp. G649-G657, 2017.

[36] T. Srinutta, A. Chewcharat, K. Takkavatakarn et al., "Proton pump inhibitors and hypomagnesemia," Medicine, vol. 98, no. 44, p. e17788, 2019.

[37] R. Schwartz and A. H. Reddi, "Influence of magnesium depletion on matrix-induced endochondral bone formation," Calcified Tissue International, vol. 29, no. 1, pp. 15-20, 1979.

[38] R. K. Rude and H. E. Gruber, "Magnesium deficiency and osteoporosis: animal and human observations," The Journal of Nutritional Biochemistry, vol. 15, no. 12, pp. 710-716, 2004. 
[39] A. Creedon, A. Flynn, and K. Cashman, "The effect of moderately and severely restricted dietary magnesium intakes on bone composition and bone metabolism in the rat," British Journal of Nutrition, vol. 82, no. 1, pp. 63-71, 1999.

[40] R. K. Rude, F. R. Singer, and H. E. Gruber, "Skeletal and hormonal effects of magnesium deficiency," Journal of the American College of Nutrition, vol. 28, no. 2, pp. 131-141, 2009.

[41] R. K. Rude, M. E. Kirchen, H. E. Gruber, M. H. Meyer, J. S. Luck, and D. L. Crawford, "Magnesium deficiency-induced osteoporosis in the rat: uncoupling of bone formation and bone resorption," Magnesium Research, vol. 12, no. 4, pp. 257-267, 1999.

[42] M. Leidi, F. Dellera, M. Mariotti et al., "Nitric oxide mediates low magnesium inhibition of osteoblast-like cell proliferation," The Journal of Nutritional Biochemistry, vol. 23, no. 10, pp. 1224-1229, 2012.

[43] M. M. Belluci, T. Schoenmaker, C. Rossa-Junior, S. R. Orrico, T. J. de Vries, and V. Everts, "Magnesium deficiency results in an increased formation of osteoclasts," The Journal of Nutritional Biochemistry, vol. 24, no. 8, pp. 1488-1498, 2013.

[44] L. Paunier, "Effect of magnesium on phosphorus and calcium metabolism," Monatsschrift Kinderheilkunde: Organ der Deutschen Gesellschaft Fur Kinderheilkunde, vol. 140, no. 9 Suppl 1, pp. S17-S20, 1992.

[45] L. Pironi, "The complex relationship between magnesium and serum parathyroid hormone: a study in patients with chronic intestinal failure," Magnesium Research, vol. 22, no. 1, pp. 37-43, 2009.

[46] R. W. Gray, J. L. Omdahl, J. G. Ghazarian, and H. F. DeLuca, "25-Hydroxycholecalciferol-1-hydroxylase. Subcellular location and properties," The Journal of Biological Chemistry, vol. 247, no. 23, pp. 7528-7532, 1972.

[47] A. Mazur, J. A. M. Maier, E. Rock, E. Gueux, W. Nowacki, and Y. Rayssiguier, "Magnesium and the inflammatory response: potential physiopathological implications," Archives of Biochemistry and Biophysics, vol. 458, no. 1, pp. 48-56, 2007.

[48] J. C. Baker-LePain, M. C. Nakamura, and N. E. Lane, "Effects of inflammation on bone: an update," Current Opinion in Rheumatology, vol. 23, no. 4, pp. 389-395, 2011.

[49] I. R. Garrett, B. F. Boyce, R. O. Oreffo, L. Bonewald, J. Poser, and G. R. Mundy, "Oxygen-derived free radicals stimulate osteoclastic bone resorption in rodent bone in vitro and in vivo," Journal of Clinical Investigation, vol. 85, no. 3, pp. 632-639, 1990.

[50] S. P. Marcuard, L. Albernaz, and P. G. Khazanie, "Omeprazole therapy causes malabsorption of cyanocobalamin (vitamin $\mathrm{B}_{-}$ 12)," Annals of Internal Medicine, vol. 120, no. 3, pp. 211-215, 1994.

[51] E. Salgueiro, T. Rubio, A. Hidalgo, and G. Manso, "Safety profile of proton pump inhibitors according to the spontaneous reports of suspected adverse reactions," Int. Journal of Clinical Pharmacology and Therapeutics, vol. 44, no. 11, pp. 548-556, 2006.

[52] B. M. Kuschel, L. Laflamme, and J. Möller, "The risk of fall injury in relation to commonly prescribed medications among older people--a Swedish case-control study," The European Journal of Public Health, vol. 25, no. 3, pp. 527-532, 2015.

[53] J. R. Lewis, D. Barre, K. Zhu et al., "Long-term proton pump inhibitor therapy and falls and fractures in elderly women: a prospective cohort study," Journal of Bone and Mineral Research, vol. 29, no. 11, pp. 2489-2497, 2014.
[54] E. Bahtiri, H. Islami, R. Hoxha et al., "Esomeprazole use is independently associated with significant reduction of BMD: 1-year prospective comparative safety study of four proton pump inhibitors," Journal of Bone and Mineral Metabolism, vol. 34, no. 5, pp. 571-579, 2016.

[55] S. L. Gray, "Proton pump inhibitor use, hip fracture, and change in bone mineral density in postmenopausal women," Archives of Internal Medicine, vol. 170, no. 9, pp. 765-771, 2010.

[56] A. Arj, M. Razavi Zade, M. Yavari, H. Akbari, B. Zamani, and Z. Asemi, "Proton pump inhibitors use and change in bone mineral density," International Journal of Rheumatic Diseases, vol. 19, no. 9, pp. 864-868, 2016.

[57] M. R. Fattahi, R. Niknam, M. Shams et al., "The association between prolonged proton pump inhibitors use and bone mineral density," Risk Management and Healthcare Policy, vol. 12, pp. 349-355, 2019.

[58] L. E. Targownik, L. M. Lix, S. Leung, and W. D. Leslie, "Proton-pump inhibitor use is not associated with osteoporosis or accelerated bone mineral density loss," Gastroenterology, vol. 138, no. 3, pp. 896-904, 2010.

[59] K. E. Hansen, J. W. Nieves, S. Nudurupati, D. C. Metz, and M. C. Perez, "Dexlansoprazole and esomeprazole do not affect bone homeostasis in healthy postmenopausal women," Gastroenterology, vol. 156, no. 4, pp. 926-934, 2019.

[60] D. H. Solomon, S. J. Diem, K. Ruppert et al., "Bone mineral density changes among women initiating proton pump inhibitors or $\mathrm{H} 2$ receptor antagonists: a SWAN cohort study," Journal of Bone and Mineral Research, vol. 30, no. 2, pp. 232-239, 2015.

[61] E. W. Yu, T. Blackwell, K. E. Ensrud et al., "Acid-suppressive medications and risk of bone loss and fracture in older adults," Calcified Tissue International, vol. 83, no. 4, pp. 251-259, 2008.

[62] Y. Nassar and S. Richter, "Proton-pump inhibitor use and fracture risk: an updated systematic review and meta-analysis," Journal of Bone Metabolism, vol. 25, no. 3, p. 141, 2018.

[63] J. Liu, X. Li, L. Fan et al., "Proton pump inhibitors therapy and risk of bone diseases: an update meta-analysis," Life Sciences, vol. 218, pp. 213-223, 2019.

[64] Y.-X. Yang, J. D. Lewis, S. Epstein, and D. C. Metz, "Longterm proton pump inhibitor therapy and risk of hip fracture," JAMA, vol. 296, no. 24, pp. 2947-2953, 2006.

[65] P. Vestergaard, L. Rejnmark, and L. Mosekilde, Proton Pump Inhibitors, Histamine H 2 Receptor Antagonists, and Other Antacid Medications and the Risk of Fracture, Springer, Berlin, Germany, 2006p. 76, -83.

[66] L. E. Targownik, A. Papaioannou, and J. D. Adachi, "The effect of proton pump inhibitors on fracture risk: report from the Canadian Multicenter Osteoporosis Study," Osteoporosis International, vol. 24, no. 4, pp. 1161-1168, 2013.

[67] J. Lee, K. Youn, J. L. Dongyoon, K. H. Song, and B. Park, “A population-based case - control study: proton pump inhibition and risk of hip fracture by use of bisphosphonate," Journal of Gastroenterology and Hepatology, vol. 48, 2013.

[68] L. Cea Soriano, A. Ruigómez, S. Johansson, and L. A. García Rodríguez, "Study of the association between hip fracture and acid-suppressive drug use in a UK primary care setting," Pharmacotherapy: The Journal of Human Pharmacology and Drug Therapy, vol. 34, no. 6, pp. 570-581, 2014.

[69] J. Ding, D. A. Heller, F. M. Ahern, and T. V. Brown, "The relationship between proton pump inhibitor adherence and fracture risk in the elderly," Calcified Tissue International, vol. 94, no. 6, pp. 597-607, 2014. 
[70] L. M. E. Moberg, P. M. Nilsson, G. Samsioe, and C. Borgfeldt, "Use of proton pump inhibitors (PPI) and history of earlier fracture are independent risk factors for fracture in postmenopausal women. The WHILA study," Maturitas, vol. 78, no. 4 , pp. $310-315,2014$.

[71] A. L. Adams, M. H. Black, J. L. Zhang, J. M. Shi, and S. J. Jacobsen, "Proton-pump inhibitor use and hip fractures in men: a population-based case-control study," Annals of Epidemiology, vol. 24, no. 4, pp. 286-290, 2014.

[72] M. M. C. van der Hoorn, S. E. Tett, O. J. de Vries, A. J. Dobson, and G. M. E. E. Peeters, "The effect of dose and type of proton pump inhibitor use on risk of fractures and osteoporosis treatment in older Australian women: a prospective cohort study," Bone, vol. 81, pp. 675-682, 2015.

[73] S.-W. Lai, C.-H. Lin, C.-L. Lin, and K.-F. Liao, "Proton pump inhibitors therapy and the risk of hip fracture in older people in Taiwan," European Geriatric Medicine, vol. 9, no. 2, pp. 169-174, 2018.

[74] B. N. Harding, N. S. Weiss, R. L. Walker, E. B. Larson, and S. Dublin, "Proton pump inhibitor use and the risk of fractures among an older adult cohort," Pharmacoepidemiology and Drug Safety, vol. 27, no. 6, pp. 596-603, 2018.

[75] J.-H. Park, Y.-M. Song, J.-H. Jung, and K. Han, “Comparative analysis of the risk of osteoporotic fractures with proton pump inhibitor use and histamine-2 receptor antagonist therapy in elderly women: a nationwide population-based nested case-control study," Bone, vol. 135, p. 115306, 2020.

[76] M. Hoff, E. Skovlund, S. Skurtveit et al., "Proton pump inhibitors and fracture risk. The HUNT study, Norway," Osteoporosis International, vol. 31, no. 1, pp. 109-118, 2020.

[77] J.-H. Park, J. Lee, S.-Y. Yu et al., "Comparing proton pump inhibitors with histamin-2 receptor blockers regarding the risk of osteoporotic fractures: a nested case-control study of more than 350,000 Korean patients with GERD and peptic ulcer disease," BMC Geriatrics, vol. 20, no. 1, 2020.

[78] J. Wei, A. T. Chan, C. Zeng et al., "Association between proton pump inhibitors use and risk of hip fracture: a general population-based cohort study," Bone, vol. 139, p. 115502, 2020.

[79] C. Reyes, F. Formiga, M. Coderch et al., "Use of proton pump inhibitors and risk of fragility hip fracture in a Mediterranean region," Bone, vol. 52, no. 2, pp. 557-561, 2013.

[80] W. Brozek, B. Reichardt, J. Zwerina, H. P. Dimai, K. Klaushofer, and E. Zwettler, "Higher dose but not low dose proton pump inhibitors are associated with increased risk of subsequent hip fractures after first hip fracture: a nationwide observational cohort study," Bone Reports, vol. 10, p. 100204, 2019.

[81] L. Wang, M. Li, Y. Cao et al., "Proton pump inhibitors and the risk for fracture at specific sites: data mining of the FDA adverse event reporting system," Scientific Reports, vol. 7, no. 1, p. 5527, 2017.

[82] S. Hussain, A. N. Siddiqui, A. Habib, M. S. Hussain, and A. K. Najmi, "Proton pump inhibitors' use and risk of hip fracture: a systematic review and meta-analysis," Rheumatology International, vol. 38, no. 11, p. 1999, 2018.

[83] T. N. Poly, M. M. Islam, H.-C. Yang, C. C. Wu, and Y.-C. Li, "Proton pump inhibitors and risk of hip fracture: a metaanalysis of observational studies," Osteoporosis International, vol. 30, no. 1, pp. 103-114, 2019.

[84] B. Zhou, Y. Huang, H. Li, W. Sun, and J. Liu, "Proton-pump inhibitors and risk of fractures: an update meta-analysis," Osteoporosis International, vol. 27, no. 1, pp. 339-347, 2016.
[85] C. S. Kwok, J. K.-Y. Yeong, and Y. K. Loke, "Meta-analysis: risk of fractures with acid-suppressing medication," Bone, vol. 48, no. 4, pp. 768-776, 2011.

[86] F. Vescini, R. Attanasio, A. Balestrieri et al., "Italian association of clinical endocrinologists (AME) position statement: drug therapy of osteoporosis," Journal of Endocrinological Investigation, vol. 39, no. 7, pp. 807-834, 2016.

[87] M. Tanaka, S. Itoh, T. Yoshioka, and K. Yamashita, "The therapeutic effectiveness of the coadministration of weekly risedronate and proton pump inhibitor in osteoporosis treatment," Journal of Osteoporosis, vol. 2014, Article ID 607145, 1 page, 2014.

[88] C. Roux, J. L. Goldstein, X. Zhou, A. Klemes, and R. Lindsay, "Vertebral fracture efficacy during risedronate therapy in patients using proton pump inhibitors," Osteoporosis International, vol. 23, no. 1, pp. 277-284, 2012.

[89] D. L. Kendler, F. Marin, P. Geusens et al., "Psychotropic medications and proton pump inhibitors and the risk of fractures in the teriparatide versus risedronate VERO clinical trial," Bone, vol. 130, no. Jan, p. 115113, 2020.

[90] D. Prieto-Alhambra, A. Pagès-Castellà, G. Wallace et al., "Predictors of fracture while on treatment with oral bisphosphonates: a population-based cohort study," Journal of Bone and Mineral Research, vol. 29, no. 1, pp. 268-274, 2014.

[91] B. Abrahamsen, P. Eiken, and R. Eastell, "Proton pump inhibitor use and the antifracture efficacy of alendronate," Archives of Internal Medicine, vol. 171, no. 11, pp. 998-1004, 2011.

[92] S. D. Yang, Q Chen, H. K Wei et al., "Bone fracture and the interaction between bisphosphonates and proton pump inhibitors: a meta-analysis," International Journal of Clinical and Experimental Medicine, vol. 8, no. 4, pp. 4899-4910, 2015.

[93] D. Asaoka, A. Nagahara, M. Hojo et al., "Efficacy of alfacalcidol and alendronate on lumbar bone mineral density in osteoporotic patients using proton pump inhibitors," Biomedical Reports, vol. 5, no. 2, pp. 165-170, 2016. 